Japanese Research in Business History 2007 | 24

\title{
The Development of the Motorcycle Production System in Hamamatsu
}

\author{
JUn ŌTAHARA \\ Doshisha University
}

\section{INTRODUCTION}

7 he Hamamatsu region, which has given birth to a large number of entrepreneurs, and is said to have followed a path of

L 'endogenous development', is known as one of the major world production centers of textiles, musical instruments, and motorcycle machinery. Motorcycle manufacture is particularly important, with Yamaha and Suzuki both having their head offices and main domestic factories concentrated in the region. The region was the birthplace of Honda, which still today has a motorcycle factory there. Since the 1960s these three firms, Yamaha, Suzuki and Honda have formed an oligopoly in the world market, and in the early 1980s, when domestic motorcycle production was at its peak, just under half the world's motorcycles were produced in Hamamatsu.

The Hamamatsu region is also home to a concentration of small and medium-sized metalworking companies which supply parts to these three final assemblers. In Hamamatsu City, Hamakita and Iwata there are a large number of industrial estates, where there are clustered together metalworking shops, the majority of which to a greater or lesser degree do work connected with the motorcycle industry. The small workshops too, scattered within the residential districts, are also secondand third-tier subcontractors for this industry. In 1976, a year when the 
domestic production was flourishing, there were 1,346 firms in Shizuoka Prefecture engaged in the manufacture or processing of motorcycle parts; of these $869(64.6 \%)$ were concentrated in the city of Hamamatsu ${ }^{1}$. Of these 1,346 firms, only 173 (12.6\%) were first-tier suppliers, with the remaining nearly 1,200 enterprises belonging to the second tier or below. People familiar with the industry say that despite a gradual decline in the 30 years since that time, the total of second- and third-tier suppliers in the region still comes to some 1,000 firms $^{2}$.

After the war the Japanese motorcycle industry, together with the camera industry, soon followed sewing-machine manufacture into the ranks of internationally competitive industries, and made a significant contribution to the acquisition of foreign currency. Research into the industry, however, has been surprisingly sparse, and an outline of the industry's development is only now becoming clear as a result of work by the author and others. This research has focused, however, on technical and management aspects of the final assemblers, with almost no research having been carried out hitherto the motorcycle parts suppliers. However, since $80 \%$ of the final product cost of a motorcycle is accounted for by parts supplied by parts manufacturers, the competitive strength of the Japanese motorcycle is in effect the competitive strength of the parts suppliers. In particular there will be an increasing need in the future for research into the type of relationship the local parts suppliers have had with the final assemblers, and into how they have been able to raise the level of their technological and managerial capability ${ }^{3}$.

In this paper I shall trace in outline how the metalworking firms in Hamamatsu have developed as suppliers of motorcycle parts. The

1. Shizuoka-ken chūshō kigyō sōgō shidō sentā [Shizuoka Prefecture SME support center], "Hamamatsu chiku ōtobai buhin seizōgyō sanchi shindan hōkokusho [Report on an analysis of the production locations of the motorcycle parts industry in the Hamamatsu district]. 1976.

2. Interview at the Shizuoka Economic Research Institute (November 29, 2004)

3. See Jun Ōtahara "Nihon no nirinsha buhin sapuraiyā - bungyō kōzō to torihiki kankei [Japanese motorcycle parts suppliers - the structure of the division of labor and business relationships]" in Yuri Satō and Moriki Ōhara, eds., Ajia no nirinsha sangyōjiba kigyō no bokkō to sangyō hatten dainamizumu [Asia's motorcycle industry - the rise of local companies and the dynamism of industrial development], Chiba, Institute of Developing Economies, 2006. 
outline of the paper is as follows. Section 2 will describe how a division of labor has developed in design and manufacture in the motorcycle manufacturing industry. Section 3 will clarify the role of the parts suppliers within this division of labor between the assemblers and themselves, and point out its significance and its limits. Section 4 will consider the characteristics of the metalworking firms that form the great majority of the parts suppliers, and look at the subcontracting policies, particularly notable in the Hamamatsu region, whereby the final assemblers use outsourcing as a means of nurturing their subcontractors, with the aim of encouraging them to raise their capabilities. The final section will present a summary of the author's conclusions, and suggest a few implications of the analysis.

II THE DIVISION OF LABOR IN THE MOTORCYCLE MANUFACTURING INDUSTRY

\section{Two types of division of labor}

The structure of the division of labor in the automobile industry, including the motorcycle industry, has traditionally been discussed with reference to the separate roles of the final assembler and of the parts suppliers in the manufacturing process. Since the 1990s, however, increasing importance has also been given to the division of labor in product development. This is because the automobile industry is a type of industry which is perpetually striving to stimulate demand by introducing new types of vehicle to the market, or by regular model changes to vehicles already on the market. From the point of view of raising their competitiveness, therefore, as well as such factors as cost, quality and delivery, the question of how to develop models that responded efficiently and in a timely fashion to customer tastes became an increasingly important issue ${ }^{4}$.

One way of developing new models efficiently and in a timely fashion is to entrust suppliers with the responsibility not only for the manufacture of parts, but also for their development. This is a point

4. See Clark, K.B. and Fujimoto, T., Product Development Performance: Strategy, Organization, and Management in the World Auto Industries, Harvard Business School Press, 1991, translated by Akihiko Tamura as Seihin kaihatsuryoku - Nichibei jidōsha mēkā 20-sha no chōsa kenkyū, Tokyo, Daiyamondo-sha, 1993. 
emphasized by the study group from Massachusetts University that investigated the reasons for the high competitiveness of the Japanese automobile industry. This paper will therefore refer below to the question of how the division of labor was carried out, not only in manufacture, but also in the field of product development.

\section{Division of labor in manufacturing}

In broad terms, a motorcycle can be said to consist of a frame, an engine, braking and suspension, exterior panel, and electrical parts. These broad categories of parts are generally referred to as 'modules', but in the motorcycle industry it rarely happens that a whole module of this sort is delivered. The various modules are further subdivided into a large number of constituent parts, which are produced by separate suppliers ${ }^{5}$. The actual number depends on how the parts are counted, but is said that dealings between suppliers and assemblers involve the supply of some 1,500 separate parts.

Only a limited number of parts are manufactured in-house by the

Fig. 1 The Structure of the Motorcycle Supplier Network

(in the Case of 150 First-tier Suppliers)

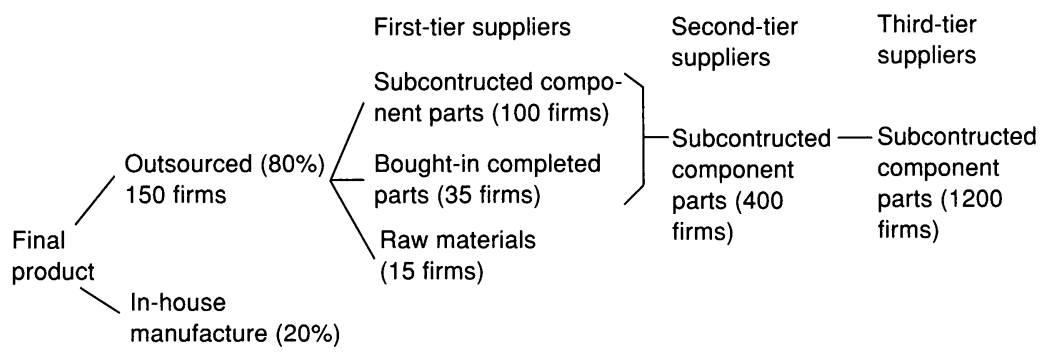

Source: Interviews

5. In recent years the delivery of 'modules' to Honda and Yamaha has become very common, and the question arises as to An important topic for historical research into economic organization is why this trend did not occur earlier, and why the division of labor developed in the direction of a minute subdivision of parts production. 
final assembler, its main role being the assembly of the engine and of the vehicle in its final form. Consequently, as stated above, $80 \%$ of the cost of the final product consists of payments to these outside suppliers. Figure 1 shows the number of suppliers and the structure of the supplier network.

According to a fieldresearch by the author, the number of first-tier suppliers dealing directly with the final assembler's plant is between 130 and 160 suppliers per plant. Business with first-tier suppliers consists of $65 \%$ to $70 \%$ of orders for outsourced component parts, $20 \%$ to $25 \%$ for bought-in completed parts, and $10 \%$ to $15 \%$ for raw materials. What are referred to as 'component parts' are parts which do not themselves have an independent function. They include such components as engine covers or casings, plastic exterior equipment and trim etc., machined, pressed or molded from metal or plastic. 'Bought-in completed parts' refer to such items as brakes, suspensions, or carburetors, which are complete in themselves with a specific function. 'Raw materials', as the term implies, refers to such goods as steel, plastics, paint and the like.

The largest number of firms is those supplying component parts, and it is this type of part that the local parts suppliers in Hamamatsu are manufacturing. They are produced by a variety of processes: machining, cutting, welding, pressing, boring, plastic molding and so on. Many of these suppliers are small or medium in scale, and these first-tier suppliers also outsource to even smaller-scale second- and third-tier suppliers, forming a multi-tiered structure.

The manufacture of many of the bought-in completed parts requires relatively high levels of technical expertise, and their suppliers predominantly belong to the final assembler's corporate group, rather than being local firms, most of which are engaged in metalworking. Their number is smaller than that of firms supplying component parts, but since the completed parts that they are supplying are high-valueadded items, they account for a relatively high proportion of the value of the final assemblers' total transactions. These completed parts are also themselves made up of a number of components, which in this case too are provided by second-tier and third-tier suppliers. Raw materials are purchased from large steelmakers or chemical companies, and since the final assembler also carries out purchasing of raw materials for its parts 
suppliers, the value of the transactions tends to be high.

It is said that in the motorcycle industry there are generally three times as many second-tier as first-tier suppliers, and three times as many third-tier as second-tier suppliers. If we exclude the suppliers of completed parts and raw materials, the remainder of the first-tier suppliers are supplying component parts, and will be local firms located in the Hamamatsu region.

\section{Division of labor in product development}

The author's field research shows that the great majority of product development in the motorcycle industry is carried out by the final vehicle assemblers. This contrasts with the division of employment in manufacturing, where $80 \%$ is outsourced to parts suppliers. It also stands in contrast to the situation in the automobile (car) industry, where according to earlier research $70 \%$ of product development is carried out by parts suppliers.

In the automobile industry, technical drawings are divided into two separate types - 'approved drawings' (shōninnzu) and 'provided drawings' (taiyozu). An 'approved drawing' is drawn up by the parts supplier in accordance with the assembler's requirements, and submitted to the assembler for approval. Consequently, when parts are designed on the basis of an approved drawing, the design work has been carried out by the parts supplier. An 'provided drawing', on the other hand, is used when the assembler designs a part, and lends the relevant drawings to the parts supplier, who then fabricates the part in accordance with the drawing. Consequently, when parts are designed on the basis of an provided drawing, the design work has been carried out by the assembler ${ }^{6}$. If we use these terms, then in the car industry the majority of suppliers are working on the basis of 'approved drawings', whereas in the motorcycle industry, by contrast, provided drawings are predominant.

An Institute of Developing Economies research project in which the present author participated found that in the motorcycle industry

6. See Banri Asanuma, Nihon no kigyō soshiki kakushinteki tekiō no mekanizumu [The mechanism of innovative adaptation in Japanese corporate organizations], Tokyo, Tōyō keizai shinpōsha, 1997. 
virtually the only parts manufactured on the basis of 'approved drawings' were carburetors, clutches, and suspensions. All of these are bought-in completed parts, with an independent function. If we take Honda as an example, these parts are developed and supplied by a firm whose accounts are consolidated with those of the Honda Motor Corporation as part of the Honda group. Yamaha obtains this type of parts from a specialist supplier, whose main work is the manufacturer of similar parts for automobiles, while Suzuki purchases them either from a wholly-owned subsidiary, from a specialist supplier, or from a firm in the Honda group. In any case, it is clear that there are very few parts manufactured from 'approved drawings' in the motorcycle industry, and the parts suppliers who do supply on this basis are either members of an assembler's corporate group, or specialist suppliers.

Why does the author emphasize this point? The reason is that almost none of the local parts suppliers in the Hamamatsu region do business on the basis of 'approved drawings'. The fact that they do not use 'approved drawings' means that they do not undertake product development. For a supplier who does not have the capacity to engage in product development there are clear limits to potential growth. This topic will be discussed in the following section.

III THE SIGNIFICANCE OF, AND LIMITATIONS ON, LOCAL PARTS SUPPLIERS.

\section{Limitations}

The role played by the Hamamatsu motorcycle parts suppliers in the division of labor with the final assemblers should now be clear. To summarize, of the parts outsourced by the final assemblers, these suppliers manufacture the low-value-added component parts, and do so according to 'provided drawings', lent to them by the final assembler. All they are supplying, therefore, is their productive capacity. It is in their role within this division of labor that we see the significance of and the limitations on the local parts suppliers of Hamamatsu. Let us consider first the limitations.

Table 1 shows the number of motorcycles produced domestically, over time. It is reported that the majority of parts suppliers active today entered the industry in the 1960s and 1970s, the period of high growth 
Table 1 Domestic Motorcycle Production (by Cylinder Capacity)

\begin{tabular}{|r|r|r|c|c|c|}
\hline & 50cc and below & $51-125 c c$ & $126-250 c c$ & 250cc and above & Total \\
\hline \hline 1955 & & 119,026 & 133,953 & 6,416 & 259,395 \\
\hline 1960 & 904,707 & 376,495 & 184,851 & 7,031 & $1,473,084$ \\
\hline 1965 & 645,601 & $1,288,599$ & 174,561 & 104,023 & $2,212,784$ \\
\hline 1970 & 895,599 & $1,407,205$ & 259,145 & 385,723 & $2,947,672$ \\
\hline 1975 & $1,030,822$ & $1,887,701$ & 331,733 & 552,291 & $3,802,547$ \\
\hline 1981 & $3,039,338$ & $2,497,799$ & 532,171 & $1,343,274$ & $7,412,582$ \\
\hline 1985 & $2,014,850$ & $1,373,423$ & 469,728 & 678,346 & $4,536,347$ \\
\hline 1990 & $1,343,220$ & 686,734 & 270,304 & 506,637 & $2,806,895$ \\
\hline 1995 & 951,803 & $1,038,938$ & 217,738 & 544,760 & $2,753,239$ \\
\hline 2000 & 636,546 & 630,221 & 297,433 & 851,191 & $2,415,391$ \\
\hline 2003 & 458,072 & 376,800 & 235,499 & 760,534 & $1,830,905$ \\
\hline 2004 & 331,449 & 304,622 & 271,126 & 832,387 & $1,739,584$ \\
\hline 2005 & 298,549 & 260,343 & 279,274 & 953,419 & $1,791,585$ \\
\hline 2006 & 306,246 & 149,868 & 276,043 & $1,039,229$ & $1,771,386$ \\
\hline
\end{tabular}

Source: Compiled from Honda Motors P.R. Dept., Sekai nirinsha gaikyō 2007-nendo ban [Outline of the world motorcycle industry, 2007 edition].

in the domestic and export markets. Today, however, as a result of the shrinkage of the domestic market, and the transfer of production overseas, their number has fallen to a quarter of its level at its peak in the early 1980s. Car production, by contrast, though falling, is far firmer than that of motorcycles, and in numerical terms five times as many cars as motorcycles are produced, and the added value per vehicle is much higher. Furthermore, the market for light motor vehicles, of which in Hamamatsu Suzuki is the main producer, continues to expand. It would seem appropriate, therefore, for the motorcycle parts suppliers to expand by diversifying into the production of parts for light motor vehicles and automobiles.

It is true that among the firms that started out as motorcycle parts suppliers there are some whose production of parts for four-wheeled vehicles exceeds that of motorcycle parts. Nevertheless, the number of firms still producing motorcycle parts is still far greater than those that have succeeded in switching to automobile parts production. Why is this the case? 
The main reason is that the motorcycle parts suppliers lack the necessary development ability. As already stated, it is inefficient for the automobiles assemblers to engage in parts development for what may number as many as 30,000 separate parts. They therefore 'entrust the whole process', from product development through to production, to the parts suppliers ${ }^{7}$. Consequently, the automobiles assemblers require their parts suppliers to possess some development ability. By contrast, since the number of individual parts in a motorcycle is relatively small, the assemblers themselves do all the design work, and lend the drawings to the parts suppliers, from whom they require only manufacturing ability. However long dealings of this sort may continue, it is unlikely that there will be any build-up of a capacity to undertake the design and development of parts. It is difficult, in short, for the majority of motorcycle parts suppliers genuinely to evolve into suppliers of parts for automobiles. This remains a problem which the motorcycle parts suppliers of Hamamatsu have yet to solve.

\section{Significance}

Nevertheless, the significance of these parts suppliers is not inconsiderable. If it is the case that in the division of labor with the final motorcycle assemblers no demands for product development are placed upon them, in what direction have their technical and managerial skills developed? The answer is that it has been in the area of improvements in quality, costs, and delivery. As a result of the clear separation of roles, between the design function of the assemblers and the manufacturing function of the parts suppliers, the latter have specialized in production technology and production control, and perfected their skills in these areas.

The local suppliers of Hamamatsu have achieved high standards of production technology and production control. This is true not only of firms with 50 or so employees, but also of smaller firms with only 10 employees or so. For example, even the small workshops scattered in the residential areas manufacture their own molds and tools, and

7. See Takahiro Fujimoto, Seisan shisutemu no shinkaron [The evolution of production systems], Tokyo, Yūhikaku, 1997. 
somewhat larger firms are able independently to design and improve their processing and assembly equipment. On the production control side, at the very minimum they will have the ability to manage quality control so making possible deliveries without inspection, delivery management on a just-in-time basis, and cost reduction through process improvement and value analysis. The production technology and production control skills of these small and medium-sized suppliers are firmly established, having developed over the years in long-term dealings with the assemblers and their strict requirements on quality, cost and delivery. Even a cursory comparison of local suppliers overseas with the local suppliers of Hamamatsu shows the clear superiority of the latter. It is precisely this capacity for continuous improvement in the area of quality, cost and delivery on the part of the approximately 1,000 small and medium-sized suppliers that has raised the international competitiveness of the Japanese motorcycle industry to its present high level.

Through what sort of process, then, have these production technology and production management abilities been formed? This is a question of particular concern to the managers of parts suppliers in Asia, which are now going through a period of growth. Of the various important factors which no doubt go to make up the answer to this question, the following discussion will focus on the subcontructing policy of the final assemblers.

\section{THE EVOLUTION OF THE MOTORCYCLE PARTS SUPPLIERS AND THE} SUBCONTRUCTING POLICIES OF THE FINAL ASSEMBLERS

\section{The early conditions in the engineering and metalworking industry}

So that we can properly appreciate the manufacturing capacity of today's local motorcycle parts suppliers in the Hamamatsu region, let us look briefly at the characteristics of the metalworking sector. The 'Report on the condition of the manufacturing areas' (Sanchi shindan hōkokusho) drawn up by the Shizuoka Prefectural SME Center and the Shizuoka Prefecture Industry and Commerce Section, points out the common characteristics of this sector as a whole. These can be summarized as 'not growing' and 'not developing'. 
Firstly, the industry on the whole has a 'subcontracting' character. In other words virtually all its products are components, or semi-finished parts of components. It is rare for a firm to sell its own completed product directly into market. Since, moreover, it is easy for customers to calculate such factors as hourly output capacity from the type and model of the machine tools being used, the unit price of orders tends to be set within tight limits. Profit margins of parts supplier tend therefore to be at a 'bare survival' level.

The second factor is the minute scale of the firms involved, and the vicious competition for orders. Since it is possible for a firm to operate with a few machine tools and a few years of technical experience, there is a continual flow of entrants into the industry. Since almost the only difference between the actual content of the tasks they perform is that determined by the capacity of the machine tools they use, there is little to set one firm apart from another. This means that firms have to compete by cost-cutting in order to secure sufficient orders, which further depresses profit levels.

When, in this way, entry into the industry is easy, the production cost structure is clearly visible, and competition is intense, it is natural that profit levels are low. If low profit levels continues, firms are unable to make new investments in processes or equipment, and are therefore unable to differentiate themselves from their competitors. If the metalworking industry continues to allow these characteristics to persist, it will be difficult for it to reach the levels of production technology and production management achieved by the Hamamatsu motorcycle parts suppliers; product development will of course remain an unattainable dream.

\section{Supplier evolution under the guidance of the final assemblers}

The motorcycle parts suppliers originally shared the characteristics of the metalworking industry as a whole, described above. Their origins can be traced to the manufacturers of parts for the weaving machinery industry, which was the main industry in the Hamamatsu region. With the decline of the textile industry in the early 1950 s, they switched to the production of parts for small motorcycles ${ }^{8}$. However, it was by no means easy for them to make this 'switch' to motorcycle parts 
production with their current levels of process technology. The production of motorcycle parts required the addition of new processes such as heat treatment and grinding, and high levels of productivity to meet the needs of large-scale mass production. Far higher levels of technical expertise were also required, for example in the processing of engine parts, which required a level of precision many times greater than that which had sufficed in the past ${ }^{9}$. It was consequently impossible for the weaving machine parts manufacturers to achieve the quality standards demanded by the front-line motorcycle makers such as Honda, Yamaha and Suzuki, relying on their already existing equipment and skills.

As a result, from the 1950s onwards, for the final assemblers, who relied on outsourcing for the greater part of their parts, the improvement of their suppliers' technical and managerial skills was an ongoing challenge. Each of these firms, Honda, Yamaha and Suzuki, set up parts suppliers' associations, and provided both technical and managerial guidance and assistance. At the same time they each pursued a policy of raising the level of dependency of the firms in these associations on their respective final assembler, and consolidating them into corporate networks (keiretsu). Below we shall consider the case of Suzuki, which was active in providing technical guidance and assistance to its suppliers, and which possessed a well-formulated policy on this matter ${ }^{10}$.

It was in 1956 that Suzuki began actively to nurture it subcontracting enterprises. In this year it established the Suzuki Motor Corporation Cooperative Union from 45 companies with which it had had dealings since the weaving machinery era. Table 2 shows the measures Suzuki

8. See Hamamatsu shōkō kaigisho [Hamamatsu Chamber of Commerce], Kukȳ̄ ni aru Hamamatsu kikaikigu kōgyō no jittai hōkokusho [Report on the plight of the Hamamatsu engineering and tool industry], 1952.

9. Suzuki Automobile Company, 50-nenshi [50-year history], 1970.

10. Shōgo Amaya, "Hamamatsu chiku no nirinsha mēkā to sono kyōryoku kōjō-gun no kinkyō [The recent condition of the motorcycle manufacturers of the Hamamatsu region and their grouping of cooperating companies]", Refarensu, 23-3, 1973, reports that as far as guidance and assistance by the final assemblers is concerned, Suzuki were the most nurturing, and the most generous with assistance, whereas Honda adopted a highly rationalistic purchasing policy, laying great weight on technical ability. Yamaha lay somewhere between these two extremes. 
adopted for nurturing its subcontractors at the time when it was doing so most intensively. The first step was the updating of equipment in firms belonging to the Union, and the introduction of machinery suited to mass production. In three stages between 1956 and 1960 it lent a total of over 200 million yen to 38 firms to finance the purchase of equipment. From 1961 onwards Suzuki built a large industrial estate of over 80,000 square meters in Kozawatari, near to its own Head Office factory, negotiating with the landowners, and putting up the money for the purchase of the land.

The funds required for firms to move to the industrial estate were provided by financial institutions, with Suzuki acting as intermediary and as guarantor of the loans. These would be repaid after the new factories went into operation. As a result a large number of firms wanted to move, but Suzuki picked out 20 firms which appeared to have potential from its point of view, and had them move to the newlyprepared Kozawatari industrial estate. Between 1961 and 1965 the firms that had relocated in this way increased their business with Suzuki at around twice the rate of the subcontractors that had not done so. Further, as a result of the prioritized and individually tailored educational assistance in the technical, accounting and managerial areas, the development of these firms was remarkable, with, for example, the defect rate on deliveries to Suzuki falling by $50 \%$. These firms were hereafter to form the core of Suzuki's motorcycle parts supplier network ${ }^{11}$.

\section{The case of Ogusu Metalworking Co.}

The Ogusu Metal Working Company, located in Hamamatsu City, joined the Suzuki Motor Corporation Cooperative Union at its inception, and has had continuous dealings with Suzuki since that time as one of its 'cooperating companies', though it has had no investment of capital from Suzuki, nor has Suzuki sent any representatives to serve in Ogusu's top management. On the one hand the firm has diversified its product range from sewing machine parts, through to motorcycle parts, automobile parts, and parts for agricultural machinery, while on the

11. Suzuki Automobile Company, 50-nenshi [50-year history], 1970. 
Table 2 The Development of Subcontractor Training by Suzuki

\begin{tabular}{|c|c|c|c|}
\hline Year & Main topic(s) & Measures implemented & Results \\
\hline $\begin{array}{l}\text { Up to } \\
1959\end{array}$ & $\begin{array}{l}\text { Encouraging formation of } \\
\text { supplier keiretsu } \\
\text { Raising standards of } \\
\text { suppliers }\end{array}$ & $\begin{array}{l}\text { - Formed Suzuki Suppliers Cooperative } \\
\text { Association } \\
\text { - Started system of business liaison } \\
\text { meetings } \\
\text { - First round of assistance with funding } \\
\text { for purchase of equipment (18 firms } \\
\text { assisted; } ¥ 71.14 \text { million) }\end{array}$ & $\begin{array}{l}\text { Establish system of } \\
\text { cooperation }\end{array}$ \\
\hline 60 & $\begin{array}{l}\text { Putting into practice } \\
\text { system for 'diagnosis' of } \\
\text { keiretsu enterprises } \\
\\
\text { Policy for strengthening } \\
\text { suppliers' capabilities }\end{array}$ & $\begin{array}{l}\text { - First keiretsu corporate diagnosis, in } \\
\text { collaboration with the SME Training } \\
\text { Center of the Shizuoka Prefectural } \\
\text { Chamber of Commerce and Industry } \\
\text { (32 companies) } \\
\text { - Second and third rounds of assistance } \\
\text { with funding for purchase of } \\
\text { equipment ( } 20 \text { companies; } ¥ 142.6 \\
\text { million) }\end{array}$ & $\begin{array}{l}\text { Shift from management } \\
\text { by intuition to } \\
\text { management by figures } \\
-------\end{array}$ \\
\hline 61 & $\begin{array}{l}\text { Start of industrial estate } \\
\text { plan }\end{array}$ & $\begin{array}{l}\text { - Began 3-year plan for preparation of } \\
85,800 \mathrm{~m}^{2} \text { industrial estate of } 20 \\
\text { supplier factories } \\
\text { - Designation received in first year of } \\
\text { national program for concentration of } \\
\text { SMEs } \\
\text { - Set up and implemented standards foe } \\
\text { evaluation of suppliers }\end{array}$ & $\begin{array}{l}\text { Strengthening of supplier } \\
\text { capabilities (both quality } \\
\text { and quantity) } \\
\text { Birth of 'Commended } \\
\text { Factories' }\end{array}$ \\
\hline 62 & $\begin{array}{l}\text { Intensification of supplier } \\
\text { training } \\
--------\end{array}$ & $\begin{array}{l}\text { - Implementation of TMC, MTP, and } \\
\text { TWI education. (Invited outside } \\
\text { lecturers; utilized in-house trainers) } \\
\text { - Implemented second Prefectural } \\
\text { keiretsu corporate diagnosis ( } 14 \\
\text { companies) }\end{array}$ & $\begin{array}{l}\text { Improvement of business } \\
\text { administration }\end{array}$ \\
\hline 63 & $\begin{array}{l}\text { Raising supplier } \\
\text { awareness of quality } \\
\text { issues } \\
\text { Promotion of cost } \\
\text { reductions } \\
\text { Shift in supplier training } \\
\text { policy } \\
--\ldots-\ldots\end{array}$ & $\begin{array}{l}\text { - Adopted registrar and inspector } \\
\text { system } \\
\text { - Strengthened measures to reduce } \\
\text { substandard products from suppliers } \\
\text { - Adopted and carried out training on } \\
\text { Value Analysis (VA) system } \\
- \text { Restricted funding assistance to } \\
\text { suppliers to reduce sense of } \\
\text { dependence } \\
- \text { Implemented third Prefectural keiretsu } \\
\text { corporate diagnosis }\end{array}$ & $\begin{array}{l}\text { Improved awareness of } \\
\text { importance of quality } \\
\text { Major cost reductions } \\
\begin{array}{l}\text { Reduction in debt and } \\
\text { debt guarantees }\end{array} \\
\begin{array}{l}\text { Thoroughgoing } \\
\text { implementation of } \\
\text { management by figures }\end{array}\end{array}$ \\
\hline
\end{tabular}




\begin{tabular}{|c|c|c|c|}
\hline 64 & $\begin{array}{l}\text { Improvement of supplier } \\
\text { quality assurance system }\end{array}$ & $\begin{array}{l}\text { - Introduced 'Quality Assurance } \\
\text { Certificate' system } \\
\text { education } \\
\text { (1) Education of managers } \\
\text { (2) Education of QC staff } \\
\text { (3) Presentation of results achieved }\end{array}$ & Reduction in reject rates \\
\hline 65 & $\begin{array}{l}\text { Completion of industrial } \\
\text { estate plan }\end{array}$ & $\begin{array}{l}\text { - Completed preparation of supplier } \\
\text { industrial estate site } \\
\text { (1) Area: } 85,800 \mathrm{~m}^{2} \\
\text { (2) No. of companies: } 20 \\
\text { (3) No. of employees: } 1,350 \\
\text { (4) Floor area of buildings: } 22,700 \mathrm{~m}^{2} \\
\text { (5) Total investment: } ¥ 613 \text { million } \\
\text { (6) Funding provided by Suzuki: } ¥ 249 \\
\text { million } \\
\text { (7) Funding from national and } \\
\text { prefectural governments: } ¥ 62 \\
\text { million }\end{array}$ & $\begin{array}{l}\text { Strengthening of } \\
\text { production capabilities }\end{array}$ \\
\hline $66-68$ & $\begin{array}{l}\text { Startup of the '20th of the } \\
\text { Month Club' } \\
\text { Further modernization of } \\
\text { equipment }\end{array}$ & $\begin{array}{l}\text { Formalization of regular meetings } \\
\text { between } 3 \text { Suzuki Department Heads } \\
\text { (Materials, Production Technology and } \\
\text { Quality Assurance) and officers of the } \\
\text { Suppliers Cooperative Association (20th } \\
\text { of every month) } \\
\text { rationalization equipment } \\
\text { - Loan/sale to suppliers of specialized } \\
\text { equipment designed and } \\
\text { manufactured by Suzuki }\end{array}$ & $\begin{array}{l}------\cdots- \\
\text { Modernization of } \\
\text { facilities }\end{array}$ \\
\hline 69 & $\begin{array}{l}\text { Establishment of new } \\
\text { factories by major } \\
\text { suppliers, accompanying } \\
\text { construction of Suzuki's } \\
\text { Toyama Plant }\end{array}$ & $\begin{array}{l}\text { - Accompanying construction of } \\
\text { Suzuki's Toyama Plant, funding } \\
\text { assistance provided to main suppliers, } \\
\text { who set up factories in Toyama }\end{array}$ & \\
\hline
\end{tabular}

Source: Compiled from Suzuki Motor Corporation, 50-nenshi [50-year History], 1970. 
other it has established an integrated processing system including cutting, gear-cutting, grinding, heat treatment and assembly.

Ogusu had progressed process innovation steadily up to the present. Thanks to renovation of tools and equipment and the strengthening of production management, the firm achieved improved productivity and a reduction in manpower, and that in recent years it has adjusted its production methods to enable it to cope with the small-batch production of multiple products. For both motorcycles and automobiles its actual products have remained unchanged over a long period, but it has clearly maintained its business relationship over a period which has seen a large number of model changes and the introduction of new types of equipment. Ever since its production skills contributed greatly to the introduction of Suzuki's front-wheel drive light car in the 1950s, it has a continuous record of supplying drive-train security parts such as universal joints, testifying to the relationship of trust it has established with Suzuki.

The improvements in productivity achieved by the firm are quite remarkable, as can be seen from the history of its process innovation on the production line for steering knuckles, its chief product. It had already introduced a fully automated production line for motorcycle transmission shafts in the 1960 s, but the production of steering knuckles poses immensely greater difficulties in terms of the number of processes, the accuracy required, and the variety of machine tools involved. It was in the late 1970s that Ogusu started the complete oneby-one production of these parts, but since then, in the third generation it achieved full automation of the process, by the fifth generation it had achieved zero setup, and by the sixth generation it completed a transfer line capable of coping with design changes and changes in the location to be processed.

Like many other parts suppliers, Ogusu is clearly part of the metalworking industry, but we can see that in the production of motorcycle shift forks and automobile steering knuckles it had achieved a level of technical expertise that served a benchmark for the industry. In manufacturing design too, by the 1950s it was already carrying out its own design work based on Suzuki's functional designs, and was developing its own equipment for this purpose. We can see how developed parts manufacturers, using their technical expertise in this 
way, were able to make use of the final assemblers' parts procurement policies at the same time as they strove to diversify their product range and their customer base.

\section{CONCLUSION}

Let us summarize our findings. First, we described the structure of the division of labor between final assemblers and parts suppliers in the motorcycle manufacturing industry, looking at both manufacturing and product development. We pointed out the fact that the majority of product development was concentrated in the hands of the final assemblers, while there was a tendency for parts suppliers to specialize in manufacture. This is a clear difference from the division of labor in the automobiles industry, where parts manufacturers are entrusted with both the design and production of parts.

Next we discussed the significance of, and the limitations on, the role of the local Hamamatsu parts suppliers, within this division of labor in the motorcycle industry. The fact that over a long period the parts suppliers have concentrated on manufacture, and have not accumulated experience in product development has made it difficult for them to adjust to the decline in domestic motorcycle production by diversifying into the production of parts for automobiles. We also saw that this was a major reason for the continuing inability of many suppliers to diversify from motorcycle parts into parts for automobiles, in Hamamatsu, a region where the production of light cars is flourishing. We also pointed out, however, the significance of the fact that, thanks to their long history of dealings with the final assemblers and their strict demands for continuous improvements in quality, cost and delivery, these suppliers have developed a high level of expertise in production technology and production control, out of proportion to the small scale of their operations. There is no doubt that this has created a firm foundation, supporting the competitiveness of the Japanese motorcycle industry.

Thirdly, in order to set the achievements of the motorcycle parts suppliers in perspective, we looked at how they developed, focused on the subcontracting policies of the final assemblers. We saw how these motorcycle parts suppliers, who started out sharing the common characteristics of an industry which 'does not grow' and 'does not 
develop', acquired high levels of technical expertise in manufacture, in production control and in management, thanks to the supportive subcontracting policies of the final assemblers, and the guidance provided by their supplier associations.

What implication can be drawn from the above discussion? It would appear, at least seen from the side of the parts suppliers, both superficial and over-optimistic to single out Hamamatsu as some sort of divinelyprotected production area for motorcycles. To be sure, The product development abilities of the final assemblers whose headquarters and factories are concentrated in Hamamatsu, and the managerial skills through which they have pulled together their suppliers, and succeeded in continuously improving their performance in terms of quality, cost and delivery are at a level achieved nowhere else in the world. The supportive and managerial skills are now, however, being transferred to production centers overseas at a remarkable pace and the quality, cost and delivery standards of the overseas local engineering and metalworking industry are rapidly improving. In other words, the role of the local parts suppliers of Hamamatsu is rapidly being taken over by local firms in Thailand, China, Taiwan and Indonesia, and although it will not happen overnight, the day is undoubtedly approaching when they will be overtaken also in the area of manufacturing technology and production control. 